\title{
MYCOPLASMA FAUCIUM AND BREAST CANCER
}

\author{
V. Mitin ${ }^{1}$, L.Tumanova ${ }^{1}$, N. Botnariuc ${ }^{2}$ \\ ${ }^{1}$ Institute of Genetics, Physiology and Plant Protection, Academy of Sciences of Moldova \\ ${ }^{2}$ Institute of Oncology of Moldova
}

\begin{abstract}
Viruses and bacteria are the cause of a large number of different human diseases. It is believed that some of them may even contribute to the development of cancer. The present work is dedicated to the identification of mycoplasmas in patients with breast cancer. Mycoplasmas may participate in the development of several human diseases including chronic fatigue syndrome, acquired immunodeficiency syndrome, atypical pneumonia, etc. Moreover, there is a reason to believe that mycoplasma can participate in the development of cancer, leukemia and lymphoma.

DNA samples from blood, saliva and tumor tissues of the Oncology Institute of Moldova patients diagnosed with breast cancer were analyzed. Mycoplasma testing was performed using nested PCR method. For Mycoplasma spp. detection, we used primers from the region of the 16S-23S RNA genes. The identification of Mycoplasma faucium, Mycoplasma salivarium and Mycoplasma orale was performed by nested PCR with primers for RNA polymerase beta subunit gene corresponding to mycoplasma.

M.faucium and M.salivarius was found in saliva at about $100 \%$, and M.orale at a frequency of about $50 \%$. Only M.faucium was found with the frequency of about $60 \%$ in the tissue of the patients.

Moreover, a fairly high rate of detection of mycoplasma is observed both in the cases when primers for RNA polymerase gene and primers for 16S-23S RNA were used.

We found M.faucium in tumor tissues of patients diagnosed with breast cancer. It is known that mycoplasmas are able to stimulate the synthesis of certain cytokines, which act as mitogenes on the cell. We assume that M.faucium can stimulate the mitogenes synthesis in breast tissues (e.g., cytokines) which, in turn, stimulate cell division and thus participate in the initiation of breast cancer.
\end{abstract}

\section{Keywords:}

Breast cancer, Mycoplasma spp., Mycoplasma faucium, nested PCR 


\section{Background}

Viruses and bacteria are the cause of a large number of different human diseases. It is believed that some of them may even contribute to the development of cancer. We assume that the bacterial and viral infections may be one of the causes of breast cancer. This assumption is evidenced by published data showing that in the tumor tissue of breast cancer patients Epstein-Barr virus (EBV) and human mammary tumor virus (HMTV) are often detected [1].

We have analyzed the possibility to detect a number of viruses and bacteria in tissues from patients with breast cancer. Preliminary tissue analysis of 10 patients with breast cancer has been carried out by PCR. Epstein-Barr virus, Cytomegalovirus, Herpes simplex virus, Herpes viruses of types 6, 7, 8, as well as as bacteria - Chlamydia trachomatis, Mycoplasma hominis, Mycoplasma genitalium, Mycoplasma complex (Mycoplasma complex set, detects a group of mycoplasmas), Ureaplasma urealiticum and Gardnerella vaginalis ware analyzed. Only Epstein-Barr virus, Gardnerella vaginalis and Mycoplasma complex were detected in the tissues after analyzing all these viruses and bacteria. These pathogens were analyzed in a more detailed study. The results of analysis of Gardnerella vaginalis were previously published [2].

The present work is dedicated to the identification of mycoplasmas in patients with breast cancer. Mycoplasma is a genus of bacteria, which is formed by a large group of microorganisms different from the conventional bacteria by a small size and the lack of cell wall. Lack of a rigid cell wall allows a close contact with the cytoplasmic membrane of Mycoplasma cell. Under these conditions, mycoplasma is hardly recognized by the immune system as a foreign organism. In addition, mycoplasma is capable of penetrating into the cell and in this way becomes an intracellular parasite. The intracellular location is a niche in which the mycoplasma is well protected from the immune system and the effect of many antibiotics. Mycoplasmas have a very small genome and, therefore, their survival depends on the host. Mycoplasmas have to use proteins, nucleic acids, cholesterol, fatty acids, etc., received from the host cells, to survive. At the same time, a disproportionately large number of mycoplasma genes are involved in cell adhesion problem and genes that contribute to the maintenance and care of parasitism surveillance by the immune system (for example, genes responsible for the synthesis of membrane antigens). Apparently, one of the main directions of mycoplasma's evolution in resolving the problem of survival is to become invisible to the immune system of the host organism. Mycoplasmas may participate in the development of several human diseases including chronic fatigue syndrome, acquired immunodeficiency syndrome, psoriasis, scleroderma, atypical pneumonia, cystitis, and Alzheimer's disease, etc. Moreover, there is a reason to believe that mycoplasma can participate in the development of cancer, leukemia and lymphoma [3]. 


\section{Methods}

DNA samples from blood, saliva and tumor tissues of the Oncology Institute of Moldova patients diagnosed with breast cancer were analyzed. Blood and saliva collection from breast cancer patients performed in the Institute of Oncology of Moldova 1 - 2 hours before tumor resection, and tissue samples - after tumor resection. All samples were stored and transported at $+4^{\circ} \mathrm{C}$. Time between sample collection and DNA isolation did not exceed 24 hours.

DNA from blood and saliva and tumor tissues was isolated using lysis buffer containing $5 \mathrm{M}$ guanidinium thiocyanate, 50mM Tris ( $\mathrm{pH} 7.5$ ), 10mM EDTA, $0.5 \%$ Triton X-100, then extracted with equal volume of phenol:chlorophorm and then chlorophorm. DNA was precipitated by 2.5 volumes of ice-cold $96 \%$ ethanol in the presence of $0.3 \mathrm{M}$ ammonium acetate. Tumor was grinded in liquid nitrogen with addition of lysis buffer before extraction.

Mycoplasma testing was performed using nested PCR method. For Mycoplasma spp. detection, we used primers from the region of the 16S-23S RNA genes and primers for the RNA polymerase beta subunit gene (Table 1).

Table 1. Primer sequences for Mycoplasma spp. testing

\begin{tabular}{|c|c|c|c|}
\hline Gene region & Primer & Sequences (5' to 3') & DNA Fragment (bp) \\
\hline \multirow[t]{4}{*}{ 16S-23S ribosomal RNA } & pM 1 & TCACACCATGGGAGCTGGTAAT & \\
\hline & pM 2 & ACGTGCCCCGCCCTACTCA & \\
\hline & pM 3 & TCCCTACGAGAACGTGGGGA & \multirow{2}{*}{$257-392 *$} \\
\hline & pM 4 & GACCCAAGGCATCCACCA & \\
\hline \multirow{4}{*}{$\begin{array}{l}\text { RNA polymerase gene of } \\
\text { M.faucium }\end{array}$} & pMf 1 & GCCTTTAGTTGCAACCGGTG & \\
\hline & pMf 2 & ACAACAGTTCCATTATGACCATGC & \\
\hline & pMf 3 & CGGAACTGTTACTTATGTCGATGC & \multirow[t]{2}{*}{459} \\
\hline & pMf 4 & CCTGCTGCAACTTCTGATCCA & \\
\hline \multirow{4}{*}{$\begin{array}{l}\text { RNA polymerase gene of } \\
\text { M.salivarium }\end{array}$} & pMs 1 & TGATGCTAACCGTGCGCTT & \\
\hline & pMs 2 & ACGTCCAGCCATCTTGTCG & \\
\hline & pMs 3 & CAGAAGCTCCATTAGTAGCAACTGG & \multirow[t]{2}{*}{538} \\
\hline & pMs 4 & CCTGCTGTTACTTCAGAACCGATT & \\
\hline \multirow{4}{*}{$\begin{array}{l}\text { RNA polymerase gene of } \\
\text { M.orale }\end{array}$} & pMo 1 & TCGACGATGTTGTTATGGCAA & \\
\hline & pMo 2 & CGCCTTCTTCAAGTTGGTCAC & \\
\hline & pMo 3 & ATGACGATGCTAACCGTGCTTTA & \multirow[t]{2}{*}{327} \\
\hline & pMo 4 & AAGGACCATCAACAAGTAAATCGC & \\
\hline
\end{tabular}

*range of DNA fragment sizes for different mycoplasmas is mentioned in the Results section. In bold are the inner primers for nested PCR analysis.

Primers were synthesized by Alpha DNA (Montreal, Quebec, Canada). 
Both rounds were 30 cycles, with $60^{\circ} \mathrm{C}$ annealing temperature. Each of the samples was analyzed twice. The amplification products were analyzed in $2 \%$ agarose gel. $100 \mathrm{bp}$. ladder (Fermentas) was used as a molecular marker.

\section{$\underline{\text { Results and discussion }}$}

Identification of Mycoplasma spp. in patients with breast cancer was carried out using primers from the region of the $16 \mathrm{~S}-23 \mathrm{~S}$ RNA genes. This region includes $16 \mathrm{~S}$ ribosomal RNA gene, partial sequence; 16S-23S ribosomal RNA intergenic spacer, complete sequence; and 23S ribosomal RNA gene, partial sequence. The length of intergenic region for any mycoplasma varies depending on the type of mycoplasma. So, use of $16 \mathrm{~S}-23 \mathrm{~S}$ primers allows not only to detect the mycoplasma, but also to effectuate a preliminary analysis of mycoplasma species. A number of human mycoplasmas, such as M.buccale (296 bp), M.faucium (286 bp), M.fermentans (387 bp), M.hominis (257 bp), M.lipophilum (373 bp), M.orale (311 bp), M.primatum (388 bp), M.salivarium (290 bp), M.spermatophilum (392 bp) may be identified using these primers.

Based on the length of DNA fragments, synthesized by nested PCR with 16S $-23 \mathrm{~S}$ primers $(\sim 280 \mathrm{bp}$. in the course of tumor tissue analyzing) we selected M.faucium, M.orale and M.salivarium for further analysis. In this, more detailed analysis we used primers for RNA polymerase beta subunit gene. Figure 1A shows the result of analysis of DNA samples for blood, saliva and tumor tissue of four patients using $16 \mathrm{~S}-23 \mathrm{~S}$ primers. Figures 1B, 1C and 1D show results of analysis of saliva samples with primers, specific for RNA polymerase gene.

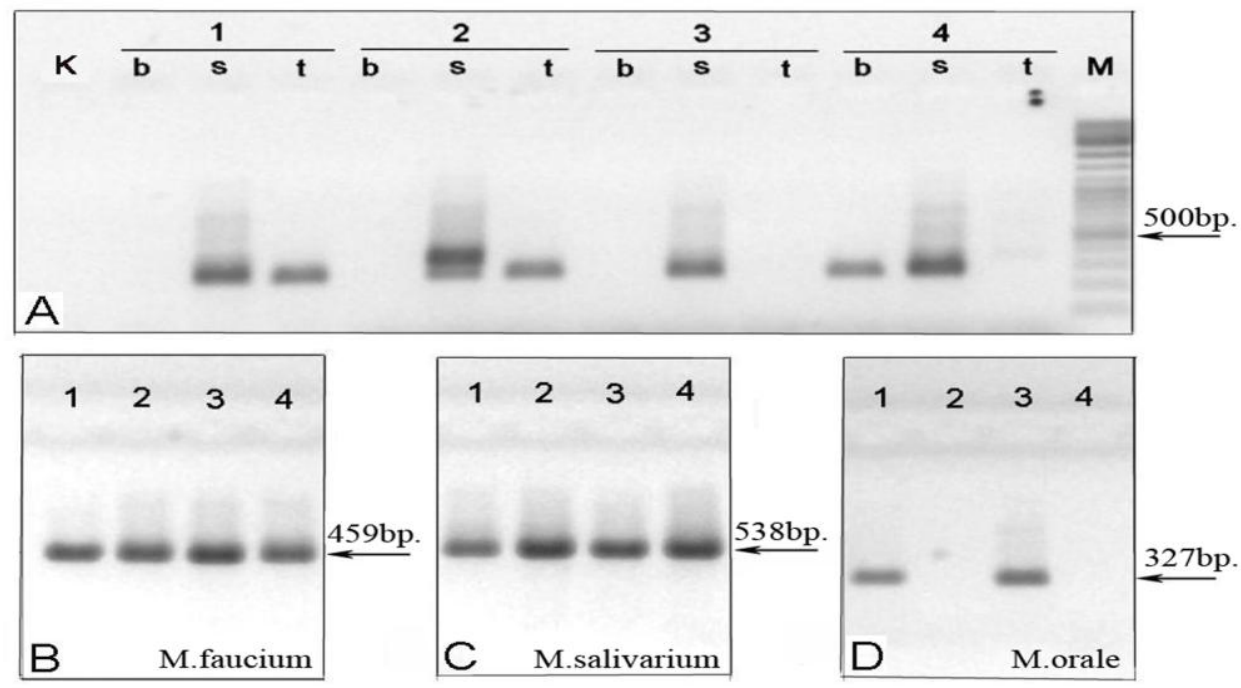

Fig. 1 . Analysis of the nested PCR obtained with the mycoplasma-specific primers on DNA of four $(1,2,3,4)$ patients. (A) - PCR analysis of DNA from the blood (b), saliva (s) and tumor tissues (t) with primers from the region 16S-23S RNA genes. (K) - negative control; (M) - molecular marker. (B, C, D) - the detection of M. faucium, M. salivarius and M.orale in saliva using primers from RNA polymerase gene. 
The length of the synthesized DNA fragments using the 16S-23S primers varied in the course of saliva samples analysis and was constant in the tumor tissues analysis. This can be explained by the fact that the saliva samples usually contain several types of mycoplasma. In this case electrophoregram pattern depends not only on the types of mycoplasma but also on the ratio of their concentrations. Constant fragment size during tumor tissues analysis may indicate that only one type of mycoplasma was present. The specificity was experimentally confirmed by PCR analysis M.faucium in the presence or absence M.salivarium, most similar to M.faucium mycoplasma according to nucleotide sequence analysis. In addition, alignment of RNA polymerase beta subunit genes of the nine listed above mycoplasmas also points to the specificity of each pair of primers used in this work (results are not shown).

Table 2 shows the results of detection of various mycoplasmas in tissue, blood and saliva of breast cancer patients. It is observed that only M.faucium may be found in the tissue of patients. Moreover, a fairly high rate of detection of Mycoplasma M.faucium is observed both in the cases when specific primers (for RNA polymerase gene) and primers for 16S-23S RNA, which are able to detect various mycoplasmas, including M.faucium were used.

Table 2. Identification of mycoplasmas in biological samples of patients diagnosed with breast cancer.

\begin{tabular}{|c|c|c|c|c|c|c|c|c|}
\hline \multirow{2}{*}{$\begin{array}{c}\text { Biological } \\
\text { sample }\end{array}$} & \multicolumn{2}{|c|}{$16 \mathrm{~S}-23 \mathrm{~S}$} & \multicolumn{2}{c|}{ M.faucium } & \multicolumn{2}{c|}{ M.salivaium } & \multicolumn{2}{c|}{ M. orale } \\
\cline { 2 - 9 } & positive & $\begin{array}{c}\text { Total } \\
\text { number }\end{array}$ & $\%$ positive & $\begin{array}{c}\text { Total } \\
\text { number }\end{array}$ & $\begin{array}{c}\% \text { positive } \\
\text { Total } \\
\text { number }\end{array}$ & $\begin{array}{c}\% \text { positive } \\
\text { Total } \\
\text { number }\end{array}$ \\
\hline Tumor tissue & 42.86 & 28 & 60.7 & 28 & 0 & 15 & 0 & 15 \\
\hline Blood & 19.3 & 57 & 9.4 & 32 & 0 & 21 & 4.8 & 21 \\
\hline Saliva & 96.9 & 65 & 100 & 31 & 100 & 20 & 55 & 20 \\
\hline
\end{tabular}

The same time, in cases where DNA from saliva was analyzed, approximately $100 \%$ of the samples were positive for both M.faucium and M.salivaium. Low frequency detection of mycoplasma in blood, together with the high frequency of detection of mycoplasma in tissue and saliva indicates the absence of false positive diagnosis of M.faucium.

Earlier [4], in breast cancer patients M.hyorhinis has been detected. Nevertheless, we failed to confirm this conclusion, using the primers of the p29 gene, specific for M.hyorhinis, (for 10 patients, data not shown). This may be due to the different localization of the Chinese and Moldavian groups of patients. The results of these studies argue high frequency of M.faucium detection in tumor tissue of breast cancer patients. But does this mean that M.faucium can really participate in the development of breast 
cancer? What can be said in favor of such assumption? Unfortunately, almost nothing is known about molecular biology of M.faucium, but its properties may be similar to those of other mycoplasmas.

For example it is known that mycoplasmas trigger the secretion of cytokines, including IL-1b (interleukin-1b), IL-2, IL-4, IL-6, IL-8, IL-10, interleukin-2 receptor (IL-2R), interferon alpha (IFN- $\alpha$ ), interferon gamma (IFN- $\gamma$ ), tumor necrosis factor alpha (TNF-a), and granulocyte macrophage-colony stimulating factor (GM-CSF)[5]. However, most of these cytokines are growth factors. This means that when they interact with appropriate receptors, D cyclins and cyclin-dependent kinases 4/6 (cdk 4/6) appear in the cell, which in turn initiate cell division. If the growth factor receptors located on the cell membrane, which are present in breast tissue, it may mean that such cytokines may promote cell division in a mammary gland. At the same time, cell division which is not controlled by the organism is one of the main (if not the main) symptom of cancer. Thereby mycoplasmas theoretically are able to participate in the development of cancer by activating cell division. Data presented in the Table 3 show that some cytokines can participate in the development of cancer.

Table 3. Some cytokines (growth factors) may participate in a cancer development

\begin{tabular}{|c|c|c|c|c|}
\hline Cytokines * & $\begin{array}{l}\text { Cytokines } \\
\text { receptors } \\
\text { (CD markers) }\end{array}$ & $\begin{array}{l}\text { Cytokines receptors } \\
\text { in breast tissues }\end{array}$ & $\begin{array}{l}\text { Regulation of genes } \\
\text { expression (cytokines as } \\
\text { mitogenes) }\end{array}$ & $\begin{array}{l}\text { Cytokines and cancer } \\
\text { development }\end{array}$ \\
\hline IL-1 $\beta$ & $\begin{array}{l}\text { IL-1R2 } \\
(\mathrm{CD} 121)\end{array}$ & $\begin{array}{l}\text { fibroblasts, } \\
\text { endothelial cells }\end{array}$ & Akt $[6,7]$, beta-catenin $[8]$ & $\begin{array}{l}\text { Colon cancer [9], breast } \\
\text { cancer }[10] .\end{array}$ \\
\hline IL-2 & $\begin{array}{l}\text { IL-2R } \\
\text { (CD122) }\end{array}$ & & Akt [11], Stat5 [12] & cervical cancer $[13,14]$ \\
\hline IL-4 & $\begin{array}{l}\text { IL-4R } \\
\text { (CD124) }\end{array}$ & $\begin{array}{l}\text { fibroblasts, } \\
\text { endothelial cells }\end{array}$ & MAPK [15], Stat6 [16] & prostate cancer $[17,18]$ \\
\hline IL-6 & $\begin{array}{l}\text { IL-6R } \\
(\mathrm{CD} 126)\end{array}$ & & STAT3 [19], RAS [20]. & breast cancer [21, 22] \\
\hline TNF-a & $\begin{array}{l}\text { FAS } \\
\text { (CD95) }\end{array}$ & $\begin{array}{l}\text { epithelium and } \\
\text { connective tissue }\end{array}$ & $\begin{array}{l}\text { MAPK, JNK, Akt [23], } \\
\text { MAPK [24] }\end{array}$ & $\begin{array}{l}\text { fibroblast proliferation[25], } \\
\text { breast tumor [26] }\end{array}$ \\
\hline GM-CSF & $\begin{array}{l}\text { GM-CSFR } \alpha \\
(\mathrm{CD} 116)\end{array}$ & $\begin{array}{l}\text { fibroblasts, } \\
\text { endothelial cells }\end{array}$ & cyclin D1[27]. & lung cancer $[28,29]$. \\
\hline
\end{tabular}

* IL-1 $\beta$ - activates T cells. IL-2 - T-cell growth factor, stimulates IL-1 synthesis, activates B-cells and NK cells. IL-4 growth factor for activated B cells, resting T cells, and mast cells. IL-6 - stimulates Ig synthesis, growth factor for plasma cells. TNF-a - a member of the epidermal growth factor (EGF) family, TGF- $\alpha$ is a mitogenic polypeptide. GM-CSF - it is a white blood cell growth factor. 
But these cytokines secretion may be triggered by mycoplasmas. This means that the mycoplasma can initiate division of those cells, which contain corresponding cytokine receptors. Since fibroblasts and endothelial cells contain receptors for above-mentioned cytokines it can be expected that mycoplasmas are able to participate in the development of breast cancer.

\section{Conclusion}

We detected M.faucium in tumor tissues of patients diagnosed with breast cancer. It may be assumed that this particular mycoplasma is somehow involved in breast cancer development.However, the detection of it in tumor tissues of patients diagnosed with breast cancer, and the data that Mycoplasma spp. could theoretically cause cell division, is unlikely to be enough to claim that M.faucium is involved in the cancer development. A stronger evidence for this would be increasing of the efficacy of breast cancer therapy by eradication of M.faucium.

\section{References}

1. Glenn WK, Heng B, Delprado W, Iacopetta B, Whitaker NJ, Lawson JS. Epstein-Barr virus, human papillomavirus and mouse mammary tumour virus as multiple viruses in breast cancer. PloS one. 2012; 7: e48788.

2. Tumanova L, Mitin V, Godoroja N, Botnariuc N. Gardnerella vaginalis and breast cancer. The Internet Journal of Oncology. 2008; 6: 2.

3. Namiki K, Goodison S, Porvasnik S, Allan RW, Iczkowski KA, Urbanek C et al. Persistent exposure to Mycoplasma induces malignant transformation of human prostate cells. PloS one. 2009; 4: e6872.

4. Huang S, Li JY, Wu J, Meng L, Shou CC. Mycoplasma infections and different human carcinomas. World journal of gastroenterology : WJG. 2001; 7: 266-9.

5. Razin S, Yogev D, Naot Y. Molecular biology and pathogenicity of mycoplasmas. Microbiology and molecular biology reviews : MMBR. 1998; 62: 1094-156.

6. Amin AR, Ichigotani Y, Oo ML, Biswas MH, Yuan H, Huang P et al. The PLC-PKC cascade is required for IL-1beta-dependent Erk and Akt activation: their role in proliferation. International journal of oncology. 2003; 23: 1727-31.

7. Lin CC, Lee CW, Chu TH, Cheng CY, Luo SF, Hsiao LD et al. Transactivation of Src, PDGF receptor, and Akt is involved in IL-1beta-induced ICAM-1 expression in A549 cells. Journal of cellular physiology. 2007; 211: 771-80. 
8. Perez-Yepez EA, Ayala-Sumuano JT, Lezama R, Meza I. A novel beta-catenin signaling pathway activated by IL-1beta leads to the onset of epithelial-mesenchymal transition in breast cancer cells. Cancer letters. 2014; 354: 164-71.

9. Kaler P, Augenlicht L, Klampfer L. Macrophage-derived IL-1beta stimulates Wnt signaling and growth of colon cancer cells: a crosstalk interrupted by vitamin D3. Oncogene. 2009; 28: 3892902.

10. Ma L, Lan F, Zheng Z, Xie F, Wang L, Liu W et al. Epidermal growth factor (EGF) and interleukin (IL)-1beta synergistically promote ERK1/2-mediated invasive breast ductal cancer cell migration and invasion. Molecular cancer. 2012; 11: 79.

11. Kelly E, Won A, Refaeli Y, Van Parijs L. IL-2 and related cytokines can promote T cell survival by activating AKT. J Immunol. 2002; 168: 597-603.

12. Martino A, Holmes JHt, Lord JD, Moon JJ, Nelson BH. Stat5 and Sp1 regulate transcription of the cyclin D2 gene in response to IL-2. J Immunol. 2001; 166: 1723-9.

13. Rangel-Corona R, Corona-Ortega T, Soto-Cruz I, Lopez-Labra A, Pablo-Arcos T, TorresGuarneros CF et al. Evidence that cervical cancer cells secrete IL-2, which becomes an autocrine growth factor. Cytokine. 2010; 50: 273-7.

14. Valle-Mendiola A, Weiss-Steider B, Rocha-Zavaleta L, Soto-Cruz I. IL-2 enhances cervical cancer cells proliferation and JAK3/STAT5 phosphorylation at low doses, while at high doses IL-2 has opposite effects. Cancer investigation. 2014; 32: 115-25.

15. Hunt AE, Williams LM, Lali FV, Foxwell BM. IL-4 regulation of p38 MAPK signalling is dependent on cell type. Cytokine. 2002; 18: 295-303.

16. Zhang WJ, Li BH, Yang XZ, Li PD, Yuan Q, Liu XH et al. IL-4-induced Stat6 activities affect apoptosis and gene expression in breast cancer cells. Cytokine. 2008; 42: 39-47.

17. Roca H, Craig MJ, Ying C, Varsos ZS, Czarnieski P, Alva AS et al. IL-4 induces proliferation in prostate cancer PC3 cells under nutrient-depletion stress through the activation of the JNKpathway and survivin up-regulation. Journal of cellular biochemistry. 2012; 113: 1569-80.

18. Lee SO, Pinder E, Chun JY, Lou W, Sun M, Gao AC. Interleukin-4 stimulates androgenindependent growth in LNCaP human prostate cancer cells. The Prostate. 2008; 68: 85-91.

19. Wang Y, van Boxel-Dezaire AH, Cheon H, Yang J, Stark GR. STAT3 activation in response to IL-6 is prolonged by the binding of IL-6 receptor to EGF receptor. Proceedings of the National Academy of Sciences of the United States of America. 2013; 110: 16975-80. 
20. Ogata A, Chauhan D, Teoh G, Treon SP, Urashima M, Schlossman RL et al. IL-6 triggers cell growth via the Ras-dependent mitogen-activated protein kinase cascade. J Immunol. 1997; 159: 2212-21.

21. Di GH, Liu Y, Lu Y, Liu J, Wu C, Duan HF. IL-6 secreted from senescent mesenchymal stem cells promotes proliferation and migration of breast cancer cells. PloS one. 2014; 9: e113572.

22. Knupfer H, Preiss R. Significance of interleukin-6 (IL-6) in breast cancer (review). Breast cancer research and treatment. 2007; 102: 129-35.

23. Rivas MA, Carnevale RP, Proietti CJ, Rosemblit C, Beguelin W, Salatino M et al. TNF alpha acting on TNFR1 promotes breast cancer growth via p42/P44 MAPK, JNK, Akt and NF-kappa B-dependent pathways. Experimental cell research. 2008; 314: 509-29.

24. Zhou JX, Fan LX, Li X, Calvet JP. TNFalpha signaling regulates cystic epithelial cell proliferation through Akt/mTOR and ERK/MAPK/Cdk2 mediated Id2 signaling. PloS one. 2015; 10: e0131043.

25. Battegay EJ, Raines EW, Colbert T, Ross R. TNF-alpha stimulation of fibroblast proliferation. Dependence on platelet-derived growth factor (PDGF) secretion and alteration of PDGF receptor expression. J Immunol. 1995; 154: 6040-7.

26. Rubio MF, Werbajh S, Cafferata EG, Quaglino A, Colo GP, Nojek IM et al. TNF-alpha enhances estrogen-induced cell proliferation of estrogen-dependent breast tumor cells through a complex containing nuclear factor-kappa B. Oncogene. 2006; 25: 1367-77.

27. Qiu C, Xie Q, Zhang D, Chen Q, Hu J, Xu L. GM-CSF induces cyclin D1 expression and proliferation of endothelial progenitor cells via PI3K and MAPK signaling. Cellular physiology and biochemistry : international journal of experimental cellular physiology, biochemistry, and pharmacology. 2014; 33: 784-95.

28. Pei XH, Nakanishi Y, Takayama K, Bai F, Hara N. Granulocyte, granulocyte-macrophage, and macrophage colony-stimulating factors can stimulate the invasive capacity of human lung cancer cells. British journal of cancer. 1999; 79: 40-6.

29. Uemura Y, Kobayashi M, Nakata H, Kubota T, Bandobashi K, Saito T et al. Effects of GMCSF and M-CSF on tumor progression of lung cancer: roles of MEK1/ERK and AKT/PKB pathways. International journal of molecular medicine. 2006; 18: 365-73. 